\title{
Multiple Social Identifications and the Family Firm
}

\author{
Curtis F. Matherne, III \\ East Tennessee State University \\ J. Kirk Ring \\ Wichita State University \\ D'Lisa N. McKee \\ Mississippi State University
}

\begin{abstract}
Through the lens of social identity theory, this article investigates the influence of the social variable of the family as a catalyst for beneficial outcomes via a stewardship orientation within the firm. The family firm provides a unique perspective in that it possesses a broader range of influential social groupings. However, multiple identifications may not associate with only positive outcomes, as conflict may arise when such identities compete. We contend that the leadership within a family firm can capitalize on the benefits associated with multiple identifications and reduce conflict in the family firm based upon members' perceptions of transformational leadership.
\end{abstract}

\section{Introduction}

Research efforts continue to focus on testing theoretical characteristics of different organizational forms. Not surprisingly, a growing number of scholars have concentrated on the family business in an effort to illustrate the distinctive and significant ways that the family unit adds to their success and sustainability. Estimates of the percentage of family businesses have been anywhere from 60\% (De la Cruz Deniz Deniz, \& Katiuska Cabrera Suarez, 2005) to $90 \%$ of all U.S. businesses (Astrachan \& Shanker, 2003; Shanker \& Astrachan, 1996). Undeniably, the focus on family business characteristics and ways to increase their success is not an insignificant undertaking since family businesses have the potential to contribute to overall socio-economic prosperity in numerous ways (Heck \& Trent, 1999).

A unique feature of the family business rests in the innate conflicts which arise when members of the business try to juggle family and business commitments, goals, resource requirements, etc. Scholars have advanced the field's understanding of these conflicts (Eddleston, Otondo, \& Kellermanns, 2008; Stafford, Duncan, Dane, \& Winter, 1999 ) by creating models depicting where and how the conflicts emerge. According to Gersick, Davis, Hampton, and Lansberg (1997), scholars originally described this divergence as one of the business and family only, but after Tagiuri and Davis' (1996) 
study, the idea emerged that the problem also existed between owners and managers. This extension led to the "Three-Circle Model of Family Business" which consists of three overlapping subsystems designated as ownership, family, and business. Individuals may be positioned within any of the subsystems alone or may find themselves in one of the four overlapping areas (Gersick, Davis, Hampton, \& Lansberg, 1997).

Even though the Three-Circle Model of Family Business provides increased nuance to the understanding of family business, the purpose of this paper is identify in a novel way the potential advantages and disadvantages of the overlap only of the family with the business. We accomplish this task by focusing on the additional socially identifiable group of the family unit within family firms. Social identity theory is founded on the assumption of an individual feeling a compelling sense of belonging to a particular group (Ashforth \& Mael, 1989) and has often been used to explain behaviors within organizational contexts. When individuals incorporate any group's identity into their own sense of self, the group identity encourages cooperation, collective thoughts and behaviors, and commitment. Research suggests that as salience with a particular group strengthens, the more precedence this group will take in relation to other groups. Individuals often espouse multiple social identities of varying strength which may include, for example, familial, social, and work group identities. We contend that the incongruence of one group becoming more important than another, rather than alignment of multiple group identities, need not be the situation within a family business. We utilize the theoretical underpinnings of agency and stewardship theories to shed light upon possible benefits from such an alignment of these social identities.

Our work argues that adoption of multiple identities within the family firm positively contributes to favorable organizational outcomes. Such outcomes can encompass a myriad of individual contributions and are encapsulated within the confines of an individual's orientation toward organizational stewardship. Stewardship theory and identification share similar theoretical underpinnings and both have been linked to beneficial outcomes in organizational contexts (e.g., Ashforth \& Mael, 1989; Davis, Schoorman, \& Donaldson, 1997). Though dual identification with both social groups can provide the greatest opportunity for stewardship orientation, as such identities compete, conflicts may arise. In order to maximize the benefits and mitigate conflicts, we contend it is the role of the family business leader to embody and facilitate acceptance of both identities.

In the following sections we review the organizational advantages of social identification and provide insight as to why social identity theory offers a particularly fruitful area for family business research. This is followed by a review of the foundations of agency and stewardship theories and their impact on the family business. From these literatures we develop propositions on the nature of steward orientation in the family firm. We conclude with a discussion of the implications for research. 


\section{Family Business and Social Identity}

The literature investigating the common characteristics and interactions of family firms has often focused on identifying a usable definition for "family business" that is broad enough to capture all types of this business form but, at the same time, narrow enough to exclude some businesses so as to create a set of companies that are unique in their activities. Owing to the plethora of current definitions within the literature, we first must designate our belief of what family business truly represents. Thus, following the work of Chua, Chrisman, and Sharma (1999), we adopt the view that a family business is defined by several components. A family business is a business that is managed by a highly dominant coalition consisting of members of the same family who have intention to shape and pursue the vision of the business. Additionally, the vision of the business is to potentially sustain its activities across generations of the family.

We believe this definition is appropriate for our conceptual approach to social identification within family firms for several reasons. First, within this definition, the areas of ownership, management, and trans-generational maintenance receive distinction which allows application to numerous businesses during the various stages of the family business life cycle (Gersick, Davis, Hampton, \& Lansberg, 1997). This definition also takes into account the three primary groups found within a family business: the owners, the family, and management. The three circle model of family business' (Gersick, Davis, Hampton, \& Lansberg, 1997) focus on systems theory gives researchers and practitioners alike an elegant and applicable heuristic to show how family businesses are distinct from non-family businesses through their actions. In using this heuristic, "it clarifies the motivation and perspectives of individuals at various locations in the overall system" (Gersick, Davis, Hampton, \& Lansberg, 1997, p. 11) and shows that having three truly distinct groups in these firms makes them operate differently than a nonfamily firm. Early research using this framework to study family businesses often focused on the problems that would arise when two of the systems would overlap. For example, a potential conflict may occur when the same individual occupies the role of both father and hiring manager. A shift in focus has occurred in recent literature to include how the overlaps of the disparate systems within the family firm can lead to higher levels of performance and better decision making. Our paper will continue this trend. Lastly, we believe the chosen definition is appropriate for the study of social identity within family businesses in particular because it accounts for the family unit's intentions and actions as a distinct and powerful group in the company. After all, the actions of the business are what truly set companies apart from one another (Chua, Chrisman, \& Sharma, 1999). We believe these intentions and actions alter the relationship between identification and stewardship.

Our work addresses the particularly important area of family business regarding the interactions of the family with the business (Habbershon, Williams, \& MacMillan, 2003; Kepner, 1991; Miller \& Rice, 1967; Stafford, Duncan, Danes, \& Winter, 1999). Bivalent attributes, which are the vital, idiosyncratic characteristics of a family firm derived from the overlapping nature of the family with the business, are developed over time (Tagiuri \& Davis, 1996). Research suggests that the characteristics drawn from this overlapping 
feature are simultaneous roles, a shared identity, a common history, emotional involvement, a private language, mutual awareness and privacy, and knowledge of the meaning of the family company. Similarly, Habbershon, Williams, and MacMillan (2003) use the tenets of the resource based view coupled with a systems perspective to describe these same overlaps inherent of a family firm and label it "familiness." They argue that the resources and capabilities created in the family firm can become distinctive or advantageous and should be exploited for generation of economic rents. Notwithstanding these ideas, it must also be noted that potential conflicts may arise from the interaction of the family and the business and minimization of these conflicts could help families successfully operate their businesses while at the same time improve the health of the family unit.

Owing to the fact that a family business possesses a distinct group that is in control of the direction of the firm, one must ask "How does the family unit contribute to firm success?" Sundaramurthy and Kreiner (2008) discuss the overlapping nature of the family unit with the business and posit that organizational identity may provide the firm with a competitive advantage. They argue that the uniqueness of the family's identity within a family firm is extremely difficult to copy by rival firms and may be an important part of the company's ability to create a competitive advantage. If this identity is utilized in a way to support the business, then an advantage may be created and sustained. Additionally, Zellweger and Kellermanns (2008) provide preliminary findings which suggest that identity within a family firm explains significant variance of firm performance. The authors operationalize family identity through the construct of family firm image, which is described as a proxy for organizational identity. It is explained that the concern often harbored by family firms over their reputation as both a business and as a family (Dyer \& Whetten, 2006) provides the impetus to find ways in which to strengthen them. Family members understand that it is impossible for them to change families if their reputation is tarnished. Coupling this with the idea that their identities are often extended then through the business, they must try to keep the family name strong and the business name strong as well (Dyer \& Whetten, 2006). Since family businesses also appear to be held in a favorable light by consumers (Cooper, Upton, \& Seamon, 2005; Sundaramurthy \& Kreiner, 2008), Zellweger and Kellermanns (2008) rightfully chose to test if family firm image truly was an advantage in the marketplace. Even though this research is beginning to show that proposed relationships do indeed exist, the current literature thus far has yet to explain "how" this occurs.

Gaining attention with Ashforth \& Mael's (1989) seminal piece, scholars have investigated the affective connection of individuals with their employing organizations and their related positive outcomes. Among many other outcomes, individuals' identification with their organizations have been linked to job involvement and both inrole and extra-role job performance (see Riketta, 2005, for review). However, the nature of the family business offers another social faction in which individuals may develop such an attachment, the controlling family. Different from non-family firms, identification with either (or both) identity(s) in the family business provides another potential source of influence for organizationally beneficial outcomes. In order to support this claim and 
the propositions building from this notion, it is imperative to briefly review some of the major theoretical underpinnings of social identity theory.

The notion of identity has been touted as one of the key foundational constructs contributing to the explanation of how individuals perceive their environments and why they behave the way they do in such environments (Ashforth, Harrison, \& Corley, 2008). Identities can serve as a device that influences the behavior of organizational members. Additionally they provide members with an interpretative framework within which behaviors occur (Whetten \& Mackey, 2002). This framework is important when there is a potential for multiple identities.

In organizational settings multiple identities can exist: organizational, work group, department, etc. Within the context of the family firm, two primary identities (the family and the business) have the potential to influence organizational members. The magnitude of potential influence is contingent upon the degree to which individuals incorporate each identity into their own self-concept, or commonly referred to as identification (Ashforth \& Mael, 1989). Through identification, individuals develop a perception of "oneness" and a distinct connection with a certain group, being like others in the group, and seeing things from the group's perspective.

The consequences of individuals' identifications with their employing firms have received much interest in organizational research over the past couple decades (see Riketta, 2005 for review). By and large, individuals with higher levels of identification have shown a positive association with a multitude of organizationally benefitting behaviors. Organizational outcomes include (but not limited to) cooperative behavior (Kramer, 2006), intrinsic motivation (van Knippenberg \& van Schie, 2000), in-role performance (van Knippenberg, 2000), and extra-role performance/organizational citizenship behaviors (Dukerich, Golden \& Shortell, 2002; van Dick, Grojean, Christ \& Wieske, 2006). These results suggest that when individuals develop identification to a referent group, they act as a microcosm of this group and, in turn, acting on behalf of the organization becomes analogous to acting on behalf of oneself. (Ashforth, Harrison, \& Corley, 2008).

Due to the numerous associated beneficial outcomes of identification, several antecedents to an individual's identification in an organizational setting have been investigated. One predictor often cited is the perceived prestige or external image of outsiders in reference to the organization (e.g. Dutton, Dukerich \& Harquail, 1994; Mael \& Ashforth, 1992). Members derive self-esteem and a sense of pride when their organization is viewed in a positive light by others. Demographically speaking, organizational tenure has been consistently recognized within this research stream as a variable positively associated with an individual's identification (e.g. Bhattacharya, Rao, \& Glynn, 1995; Mael \& Ashforth, 1992), in that as individuals remain in organizations, they become engrained and attached to the identity of their organizations and act in their best interests. Lastly, a growing area in the identity literature is the role of the leader (specifically transformational leaders) affecting the identification of individuals in organizational settings. Multiple studies have identified a positive association between 
transformational leadership and member identification (e.g. Epitropaki \& Martin, 2005; Kark \& Shamir, 2002; van Knippenberg, van Knippenberg, De Cermer, \& Hogg, 2004).

As previously noted, we assert the family business contains the possibility for individuals to associate with two separate social units: the business or family. Furthermore, and as will be discussed, individuals can also identify with both simultaneously. The degree to which these identities diverge (or converge) can vary from case to case (e.g. Sundaramurthy \& Kreiner, 2008). As convergence happens there is less potential for identity conflict as the goals and values of both identities overlap to a greater degree. Thus, dual identification with convergent identities assists the realization of organizationally beneficial outcomes and we argue this convergence may be facilitated by the family business leader.

Social identity allows individuals to define 'who they are' in the context of what groups they perceive themselves affiliated. Through identification, individuals undergo depersonalization which can influence actions to abide by group norms and to promote the group's best interest. We believe the conditions of business and family commitments will assist in the creation of bivalent attributes or "familiness" to overcome conflicts, create synergies, and lead to competitive advantages and economic rents. We contend that the family business leader plays a major role in maintaining and harmonizing these identities and relevant attachments within the family firm. To better explain these points, we utilize the tenets of agency and stewardship theories to recognize how these competitive advantages and disadvantages may transpire.

\section{The Family Firm: Agents and Stewards}

It is a commonly held belief that the separation of ownership and control within firms creates costs for which must be accounted. Agency theory is predicated on the idea that non-owner managers will not handle the affairs of a firm as conscientiously as ownermanagers. Agency theory describes the relationship in which the owner delegates work to the manager who then performs that work (Ross, 1973) and this relationship has been defined as one of principals and agents. The separation of ownership and control within the firm causes the interests and objectives of the principal/owner and the agent/manager to differ. Since the manager is not the owner of the firm, he lacks the disincentive associated with a loss in equity value due to actions not in the best interest of the firm. Principals attempt to limit departure from their interests by offering monetary incentives and by instituting control mechanisms to monitor actions of the agent and these activities have been coined "agency costs."

Adverse selection and moral hazard (Demski, \& Feltham, 1978) arise from principal/agent interest conflicts and asymmetric information (Eisenhardt, 1989) and lead to agency costs. Adverse selection refers to the falsification of ability, commitment, or interests by the agent. Moral hazard, on the other hand, refers to actions of the agent taken in his best interest which is subsequently unfavorable for the principal. The action observed is less than or not in accordance with effort outlined in the work contract between the principal and agent and can thus be considered shirking. 
Traditionally, claims have been made that owner-managed firms will either lack agency costs altogether or those costs would be somewhat insignificant (e.g., Ang, Cole, \& Lin, 2000; Jensen \& Meckling, 1976). Stewart (2003) and others extend this claim to family firms because members of the family are presumed to exhibit altruistic behaviors towards each other and this results from the obligations created through their kinship. The argument has been made that when family members become managers, agency costs should also be reduced because of the lack of separation of management and control decisions. Also, the agents are better equipped to monitor and discipline employees (James, 1999). Additionally, by utilizing implicit, close knit, familial relationships, family firms may forgo the expense of creating and monitoring explicit, formal contracts.

Chua, Chrisman, and Sharma (2003) contend the reduction of agency costs in the family firm also relies upon the presence of reciprocal altruism (Becker, 1974, 1981; Eaton, Yuan \& Wu, 2002; Wu, 2001) or stewardship behaviors of the managers (Davis, Schoorman, \& Donaldson, 1997). Altruism involves a moral value that encourages individuals to carry out actions that benefit others aside from any prospect of external reward (Batson, 1990). Altruism induces parents' concern for their offspring, promotes consideration amongst family members, and infuses family membership with value in ways that strengthen the family bond (Eshel, Samuelson, \& Shaked, 1998; Simon, 1993). Also, altruism takes on a reciprocal nature because the interests or welfare of one individual is positively linked to the interest or welfare of another (Bergstrom, 1989).

In opposition to this viewpoint, Buchanan (1975) notes that altruism can cause parents to imperil their offspring with moral hazard. As altruism, to a degree, originates from parents' desires to enhance their own welfare, parents have an inducement to be generous even as their munificent behavior may increase the propensity of the children to free-ride. Also, asymmetric altruism in the family firm may explain biased performance assessments, contract enforcement difficulty, and excessive benefit consumption (Schulze, Lubatkin \& Dino, 2001, 2003). Therefore, mixed views exist on the true level of reduction of agency costs in family firms when only considering the actions of the family members.

Van den Berghe and Carchon (2003) address issues specific to non-family workers in the family firm. They explain asymmetric altruism can produce an intricate set of agency problems that may affect all business relationships in the family firm. For example, nonfamily executives may be held more accountable for their actions than family executives because they do not have family bonds (Gomez-Mejia, Nunez-Nickel, \& Gutierrez, 2001). Therefore, altruistic behavior can cause the firm's non-family agents to experience a feeling of "distributive injustice" (Van den Berghe \& Carchon, 2003). Owing to these possibilities, it is difficult to believe that family firms are totally impervious to the problems associated with principle-agent separation. Thus, something else must be present that accounts for the claims that family firms possess competitive advantages over non-family firms. 
While agency theory focuses primarily on the divergence of interests between the owner and manager, stewardship theory concentrates on the alignment of interests of owners and managers. With its roots in sociology and psychology, stewardship depicts individuals as having higher-order needs for self-esteem, self-actualization, and affiliation (Arthurs \& Busenitz, 2003). A steward's behavior is regarded as organizationally centered and his actions are derived from and aimed at the principal's contentment and organizational successes. This involves a relationship of trust where the word of the steward can be taken as his or her bond (Williamson, 1975).

Stewardship theory's foundation rests upon the belief that a steward is an individual who orders his behaviors such that pro-organizational, collectivistic behaviors provide greater utility than individualistic, self-serving behaviors (Davis, Schoorman, \& Donaldson, 1997). Further, Argryis (1973) describes a steward as one who works beyond self-serving needs to one that is directed at the needs and values of the principal. Stewards believe working for organizational objectives diligently will facilitate acquisition of their own personal needs (Davis, Schoorman, \& Donaldson, 1997).

Davis and colleagues also described governance structures conducive to success for steward behaviors. When a steward's "autonomy" is intentionally broadened, due to high levels of trust from the principal, he or she will complete tasks more effectively than when control mechanisms are put in place to monitor actions. Therefore, the control mechanisms that work well to align goals or control a traditional, opportunistic manager may actually hinder the motivation or control of a steward (Lee \& O'Neill, 2003).

Corbetta and Salvato (2004) suggest through an analysis of family firm literature that the propensity for one to act as a steward in the family business setting is impacted through the role played by family goals, trust, emotions and sentiments, and their influence on relational contracts. When goals within the family firm are strictly economically based, lower order needs are accentuated and the inclination for agency behavior is more prevalent. As more non-economic goals are emphasized, higher-order needs are realized and the tendency for steward behaviors begins to take hold (Corbetta \& Salvato, 2004).

The level that emotions and sentiments are entrenched into family bonds and the impact of these bonds play a key role in shaping behavior. Additionally, the level of altruism in the family firm may affect stewardship behavior. Altruism, from a selfactualizing, collective perspective, does not encompass a desire for reciprocal behavior (Gomez-Mejia, Nunez-Nickel, \& Gutierrez, 2001). Subsequently, family members consider themselves owners of the firm and should act in accordance with interests of the business because they regard this as meeting their personal needs without expectation of similar actions in return.

This analysis of agency and stewardship in the family firm provides insight into potential desired behaviors, but fails to specifically address mechanisms or moderating effects leading to such behaviors. Given the orientation of stewardship, our contention is that social identity may provide a lens to understand and further steward behaviors that have 
been underexplored in prior research. With this endeavor, we may be able to better explain "how" the family unit within the firm is able to create a competitive advantage.

\section{Stewardship Orientation in the Family Firm}

The tendency of an organizational member to adopt the role of a steward can create numerous benefits within the firm. Stewardship orientation is the proclivity of individuals to engage in behaviors that are targeted towards organizational interest over immediate self-interest. This orientation of individuals within a firm is consistent with the tenets of stewardship theory (Davis, Schoorman, \& Donaldson, 1997). These behaviors can range in type, but are predicated on the fact that the target is for organizational gain, overall favorable light, or prestige.

Steward behaviors not only enhance performance, but also provide some individual benefits. Le Breton-Miller and Miller (2009) suggest that stewardship behaviors can have a direct benefit to family members employed by a family business, as stewardship allows them to contribute to the business and even feel useful. Behaving in the interest of the family business may then allow them to derive psychological benefits such as improved affect, increased self esteem, intrinsic satisfaction, and a sense of personal achievement (Le-Breton-Miller \& Miller, 2009; Zahra, Hayton, Neubaum, Dibrell, \& Craig, 2008). The tenets of stewardship theory also suggest that family members in family firms will be motivated to invest in the future of the firm (Le-Breton-Miller \& Miller, 2009).

The initial conceptualization of stewardship theory in family businesses suggests that there are distinct, long-term performance benefits associated with stewardship behaviors (Davis, Schoorman, \& Donaldson, 1997). Studies such as those by Zahra, Hayton, Neubaum, Dibrell, and Craig (2008) further this argument and show that stewardship can enhance strategic flexibility and the ability to more rapidly adapt in changing environments. Specifically, their study found that actions such as encouraging collectivism in the family firm and providing an environment of care and concern had stronger relationships with strategic flexibility than did a self-report of how stewardship motivated a firm member.

Beginning with the work of Davis Schoorman, and Donaldson (1997), an individual's affective attachment to any group and/or organization has been linked to a stewardship orientation. Given that, when individuals adopt a social identification to some organization, they more readily engage in cooperative, altruistic behaviors promoting the successes of the organization. As the identification is the perception of oneness with some social aggregate (Ashforth \& Mael, 1989), individuals attribute reflections of the organization into their own self-image and self-concept. Simply, the organization becomes self-defining, and thus the organizations' successes are the individuals' successes. Stewardship theory suggests that individuals who act as stewards do so with a communalist mindset; that is, they put the interests of others over their own self interest (Davis, Schoorman, \& Donaldson, 1997). While, in the traditional principal-agent relationship (Jensen \& Meckling, 1976), an agent is expected to behave in their own self 
interest if not otherwise motivated by the principal, a steward does not require the same prompting. Rather, a steward is intrinsically motivated to perform behaviors that benefit the organization without any external prompting.

\section{Proposition 1: Identification is positively associated with stewardship orientation.}

The focus of analysis in this manuscript is the family firm for multiple reasons. First, the social identity literature lacks a focus on implications for the family business and identification research thus far been scant concerning studies specific to family firms. Thus, research examining the notion of identity within family firms is in the infancy phase at best (e.g. Carmon, Miller, Raile, \& Roers, 2010; Sundaramurthy \& Kreiner, 2008; Zellweger \& Kellermanns, 2008). Therefore, a potential gap in our knowledge of both family firms and social identification exists. Scholars assert that controlling families do indeed have a specific identity within family firms, but the organizational impact of individuals' adoption of these identities for firms has yet to be fully elucidated. Family firms provide a unique social group which individuals identify with that is atypical of other firms. The family as a distinct social group can exemplify cooperative values in which one is drawn to and desires association. Second, it has been shown that agency/steward relations in the family business are not prototypical of those observed in publicly held companies (Chrisman, Chua \& Litz, 2004). The family business structure supports alignment of goals between the principal and agent due to the fact that they are one in the same. The structure also influences the "model of man" prevalent in the family firm "through the role played by family goals, degree of altruism, degree of trust, emotions and sentiments, and their influence on relational contracts" (Corbetta \& Salvato, 2004).

Over the past decade, less than 10 percent of family business research has focused on topical areas outside strategic management (Debicki, Matherne, Kellermanns, \& Chrisman, 2009). Therefore it is understandable that scholars have only recently begun to explore the potential impact that identifying with the controlling family can have on the organization and its relevant outcomes. Preliminary findings show a linkage to family identity and organizational outcomes (e. g. Carmon, Miller, Raile, \& Roers, 2010; Zellweger \& Kellermanns, 2008). Prior identification research on varying organizational related foci has shown relationships to organizational outcomes. Furthermore, it is suggested that differing foci may relate more strongly to outcome variables than identification with the organization. Riketta and Van Dick (2005) found that workgroup attachment is stronger than organizational attachment and more strongly related to organizationally relevant outcome variables. Also, in a sample of workers across various industries, Becker, Billings, Eveleth and Gilbert (1996) found that affective attachment to the supervisor was not only positively associated with job performance, but also more robustly associated that individual's attachment to the organization.

Recent works have begun to explore the dynamic of dual identities existing within the family firm (e.g. Shepherd \& Haynie, 2009; Sundaramurthy \& Kreiner, 2008). Identities have a sense-giving function that guides how individuals should behave (Ravasi \& Schultz, 2006) and each identity (even when highly similar) has definitive nuances and 
role expectations. Shepherd and Haynie (2009) differentiated the role expectations typically associated with family and business identities. The family identity rests itself more on an intrinsic focus (nurturing, care giving, commitment and loyalty to the family), whereas the business identity is predicated primarily on extrinsic attributes (income, growth, public success, and social legitimacy).

Following proposition 1, we believe identification with either the family or the business should promote a stewardship orientation in the family firm. However, the nature of the identity may also influence an individual's behavior. The family identity lends itself more to the theoretical underpinnings of stewardship theory, in that both are rooted in intrinsic motivations and values. Stewards strive for higher purpose in their organizational life, which leads them to be motivated by forces other than just economic self-interest (Davis, Schoorman, \& Donaldson, 1997; Miller \& Le Breton-Miller, 2006).

\section{Proposition 2: Family identification is more strongly associated with stewardship orientation than business identification.}

Ideally, if an individual identifies strongly with the family and business identities, the opportunity for higher levels of stewardship orientation is present. This is due to the entrenchment of dual identifications and the influence of those affective attachments on potential behaviors. However, this scenario also presents unique consequences. As articulated by Sundaramurthy and Kreiner (2008) business and family identities may exist along a continuum in the family firm ranging from differing levels of convergence and divergence.

Applying this rationale for managing multiple identities (e.g. Foreman \& Whetten, 2002), it is plausible that the values associated with identifying with the family can conflict with the values associated with identifying with the business. Identity conflict refers to situations where the demands of one role (identification) impede the progress for satisfying expectations of another role (identification) (Ashforth \& Mael, 1989). For instance, this could be viewed in a situation where family managers are torn between the use of excess profits for reinvestment in the firm's operations and using the funds to close the business for a vacation. Funds and/or days of operation used in a recreational manner satisfy the expectations of the family identity, in that it promotes well-being and commitment. However, the expense and days lost of operation would compete with the business identity roles involving economic benefit (income and growth).

Based on the rationale of this example, or any other scenario which may create tension between what is best for the business and what is best for the family, it is possible for dual identification to create problems for the family business. Due to the nature of the conflict, in that both identities have differing goals and/or values, acting on behalf of one may in turn violate the other. Consequently, we expect that stewardship orientation would be diminished when the identities diverge owing to inherent conflict between the two. 
Proposition 3: As the family and business identities' values and goals converge, dual identification leads to greater levels of stewardship orientation; when family and business identities' values and goals diverge, dual identification leads to lower levels of stewardship orientation.

This discussion leads to an important question. What can be done to increase the integration of family and business identifications and subsequent stewardship orientation? We believe one solution may reside in the leadership within the family firm. Among the unique characteristics of family businesses is the level of control and influence the founding family has on psychological and situational antecedents of individuals' behaviors within the organization (Vallejo, 2009a). One such way the family has influence on firm employees is through leadership. Leaders within the family firm have the opportunity to create and sustain the identities important for firm performance and success. Of particular interest is transformational leadership, as empirical studies on family businesses have found that leadership in family firms is more transformational than it is in otherwise similar non-family firms (see Vallejo, 2008; 2009b).

Transformational leaders motivate employees by uniting them with a vision and similar interests. Research has shown that family firms provide a particularly fruitful environment for transformational leadership to flourish. Most notably, the leader will ideally experience less resistance from employees, resulting in a reduced need for a more transactional approach. Due to the predisposition of family member employees to share similar goals, buy-in for the vision may be more easily achieved than it is in nonfamily firms where employees do not inherently share similar goals. Furthermore, these shared goals can diminish the need for transactional leadership, thus making transformational leadership a more viable and sustainable form for the family business (Vallejo, 2008, 2009b). Therefore, we believe transformational leaders within the family firm have the ability to integrate identities toward a common purpose and consequently create an environment conducive for a stewardship orientation.

Eddleston argued that transformational leadership can encourage family firm members to "go beyond the status quo" (2008, p. 1058), and thus move beyond behaviors that might otherwise be more self-interested or agent-like in behavior. Furthermore, these leaders can be stewards themselves (Miller \& Le Breton-Miller, 2006). Family members who serve as leaders in the business may experience increased self-esteem and selfactualization, along with deriving satisfaction from increasing the "value" of their family name through the business. Lastly, leaders in family businesses on average tend to remain longer than their non-family business counterparts, which may also encourage individuals to act as stewards if they anticipate having a long career with the business (Miller \& Le Breton-Miller, 2006). Especially in situations where identities within the firm may conflict, it is the responsibility of the leader to embody, articulate, and integrate these identities in such a way that others within the firm can accept and advocate. This is accomplished through the four dimensions common to transformational leaders: idealized influence, inspirational motivation, intellectual stimulation, and individualized consideration (Bass, 1985). The author described the four dimensions as actions rather than simply characteristics and therefore each can be improved if given proper 
attention. Idealized influence aligns followers by providing a common purpose and this is accomplished through the effect of the leader's charisma on the identification of followers. Inspirational motivation is the manner in which the leader articulates a vision or beliefs in a pleasing way that is easily understood by followers. Intellectual stimulation refers to the ability of leaders to challenge old paradigms and solicit input from employees. Lastly, individualized consideration refers to the degree to which leaders are attentive to employee needs and concerns and serve as a mentor.

These dimensions can be actively used to integrate identities. Accomplishing this task within a family business may be less difficult than expected for a number of reasons. First, a family member who is also a leader of the firm typically embodies both the family and the business personifications. Also, the potential for constant communication outside the daily grind of business activities provides the family firm leader with the opportunity to better attend to needs and concerns of particular family members. This increased communication serves as a bridge to help followers more readily understand the current vision of the family and the business units. Finally, in many instances the family business leader will be more available to family members who work in the firm to bring forth their new ideas for the activities of the firm.

Through these actions the family firm leader reduces identity conflict that occurs when family and business needs are incongruent. These actions may help members of the firm to understand the needs of both groups and thus temper their dissatisfaction with decisions that on the surface appear to favor one over the other. Therefore, by using these mechanisms to raise and integrate individuals' identification within the firm, transformational leaders can have a direct influence on stewardship orientation within the family business context.

Proposition 4: As the family business leader displays characteristics of a transformational leader, identity conflict decreases and stewardship orientation increases.

\section{Limitations and Future Research}

Despite trying to close the gaps in these literature streams, our work does contain several limitations and potential pitfalls. We did not address the idea that increasing the social identity of all members of the family business, including non-family members, may decrease the commitment gap in times of need. The concept of a lifetime job for U.S. workers has all but died in recent years but we may not be too far removed from this idea to instill a sense of ownership to all employees in family businesses. According to Beehr, Drexler and Faulkner (1996), family members are more satisfied with their careers and show signs of stronger commitment to the business. They are also more likely to stay with the company when economic times are bearish. It may be difficult in some instances for the family business leader to effectively encourage non-family members to identify with the family unit. Even so, we believe that simply persuading them to identify with the business will be better than no identification at all. Addressing this issue in future work will be necessary. 
Another area of concern is the assessment of individual worker productivity when members of the business are being motivated towards collective goals (Ellemers, DeGilder \& Haslam, 2004). Ellemers and colleagues go on to show that the process of motivation is unclear if personal goals and expectations are not compatible with the overall objectives of the business and the family. Therefore, creating a social identity with the family that is incongruent with the activities and goals of the workers may cause mixed signals and could have ill effects on steward behavior.

Also, disadvantages may develop from leader prototypicality and from the strength of employee social identity. In the family business, as in most businesses, members of the business strive for advancement and power throughout their careers. Specifically in the family business though, actions of altruism and nepotism may cause separation of the groups which can lead to agency behavior amongst non-family employees. As family members try to protect their leadership status, they may consequently exhibit behaviors that facilitate intergroup behavior instead of intragroup behavior (Hogg, 2001). Another pitfall comes from the strength of the social identity coupled with prototypical leader ability. Groupthink (Janis, 1972) situations may occur when members of the family business are so engrained to the collective ideals that they do not consider new and innovative actions.

A final limitation of our paper is the need to address families that simply are not "good families" or "ethical families." It would be unrealistic to position our paper on the idea that all families act in accordance with the law or, even more simply, that all families' actions as a unit are beneficial to the sustainability of the business. Therefore, the premise of the arguments in our paper currently focus on those families that are running their businesses in a accordance with the law and with an eye towards long-term, transgenerational wealth production for both the business and the family units (Chua, Chrisman, \& Sharma, 1999).

This paper only addresses the orientation towards behaviors that positively impact the family business due to identification with not only the organization, but the controlling family. The outcome variables herein have been constrained within the theory of organizational stewardship; outcomes are organizationally directed. However, future research may want to assess if such an orientation could also lead to behavioral outcomes that while positively impacting the family (and hence the family business) are a potential detriment to another faction of society. Recent work has shown a positive relationship with organizational identification and types of unethical pro-organizational behaviors (Umphress, Bingham, \& Mitchell, 2010).

A need is evident for empirical research and study for growth of stewardship through social identity. As there has been no prior research integrating the ideas expressed in this manuscript, there is potential value to all fields discussed. Hogg (2001) developed an eleven item measurement for group identification that may prove useful in this endeavor. A continuation of Hogg's work when applied to the family firm should provide interesting results. Furthermore, Zahra and colleagues (2008) assessed individual's 
stewardship motivations within the context of family firms via a five item measure. An adaptation of their work could provide the avenue to evaluate stewardship orientation of family business members. Unfortunately, publicly available data concerning family firms is an immediate limitation, as most firms are privately held and do not disclose information that could be useful for analysis.

As argued above, an important characteristic of family businesses is that they often require individuals to align with one or both of the collective groups found in a family business. Consequently, employees are expected to take on the ideals and goals of the group which in turn surrenders their own individual goals to reach shared results. Though not much has been done to further knowledge concerning team motivation (Ellemers, De Gilder, \& Haslam, 2004), the information presented here provides a new way to discuss alignment of goals in teams.

The highly researched topic of succession in the family business literature also offers an interesting angle for social identification research. It is widely known that many family businesses cease to exist into their third generation and identification may be a fresh way to explain this phenomenon. The prototypicality of the family business leader is an important factor in self-categorization and the salience of a group social identity. If the rightful heir to a family firm does not hold the prototypical attributes of the current family business leader and the ability to exemplify the values inherent of both identities, many of the possible synergistic effects of dual identification with the family and the business will be lost.

\section{Conclusions}

This manuscript uses the lens of social identity to describe synergistic opportunities derived from interactions of the family unit with the business entity in family businesses. In our review of the literature we brought forth several concepts which ultimately lead to a discussion of "how" family firms may take advantage of these opportunities. We discussed the way agency relationships may take on different characteristics due to the degree of family involvement and altruistic behaviors of family members. Also, we described how the family business may enlist the ideals of stewardship rather than agency owing to the communal nature and value structure of the family unit. We use theory to argue that steward behaviors provide significant advantages to organizations. From this, we believe that the family firm offers a distinctive setting for the study of identification, because identification has been shown to bring about steward-like behaviors. However, this does not come without limitations because identity conflict may arise as a result of differing values and goals. Consequently, we used the tenets of transformational leadership to show that perceptions of leadership within the firm can mitigate the potential for conflict. We believe this further enhances identification and stewardship. 


\section{References}

Ang, J. S., Cole, R. A., \& Lin, J. W. (2000). Agency costs and ownership structure. Journal of Finance, 55(1), 81-106.

Argryis, C. (1973). Organization man: Rational and self-actualizing. Public Administration Review, 33(4), 354-357.

Arthurs, J. D., \& Busenitz, L. W. (2003). The boundaries and limitations of agency theory and stewardship theory in the venture capitalist/entrepreneur relationship. Entrepreneurship Theory and Practice, 28(2), 145-162

Ashforth, B. E., \& Mael, F. (1989). Social identity and the organization. Academy of Management Review, 14(1), 20-39.

Ashforth, B. E., Harrison, S. H., \& Corley, K. G. (2008). Identification in organizations: An examination of four fundamental questions. Journal of Management, 34(3), 325-374.

Astrachan, J. H. \& Shanker, M. C. (2003). Family businesses' contribution to the U.S. economy: A closer look. Family Business Review. 16(3), 211-219.

Bass, B. M. (1985). Leadership and performance beyond expectations. New York: Free Press.

Batson, C. D. (1990). How social is an animal? The human capacity for caring. American Psychologist, 45(3), 336-346.

Becker, G. S. (1974). A theory of social interaction. Journal of Political Economy, 82(6), 1063-1093.

Becker, G. S. (1981). A treatise on the family. Cambridge, MA: Harvard University Press.

Becker, T. E., Billings, R. S., Eveleth, D. M., \& Gilbert, N. W. (1996). Foci and bases of commitment: Implications for performance. Academy of Management Journal, 39(2), 464-482.

Beehr, T. A., Drexler, J. A., \& Faulkner, S. (1997). Working in small family businesses: Empirical comparisons to non-family businesses. Journal of Organizational Behavior, 18, 297-312.

Bergstrom, T. C. (1989). A fresh look at the rotten kid theorem and other household mysteries. Journal of Political Economy, 97(5), 1138-1159.

Bhattacharya, C. B., Rao, H., \& Glynn, M. A. (1995). Understanding the bond of identification: An investigation of its correlates among art museum members. Journal of Marketing, 59(4), 46-57.

Buchanan, J. M. (1975). The Samaritan's Dilemma. In Phelps, E. S. (Ed.), Altruism, Morality and Economic Theory (pp. 71-85). New York: Russell Sage Foundation.

Carmon, A. F., Miller, A. N., Raile, A. N. W., \& Roers, N. M. (2010). Fusing family and firm: Employee perceptions of perceived homophily, organizational justice, organizational identification, and organizational commitment in family businesses. Journal of Family Business Strategy, 1(4), 210-223.

Chrisman, J. J., Chua, J. H., \& Litz, R. A. (2004). Comparing agency costs of family and non-family firms: Conceptual issues and exploratory evidence. Entrepreneurship Theory \& Practice, 28(4), 335-354.

Corbetta, G. \& Salvato, C. (2004). Self-serving or self-actualizing? Models of man and agency costs in different types of family firms: A commentary on "Comparing the 
agency costs of family and non-family firms: Conceptual issues and exploratory evidence. Entrepreneurship Theory and Practice, 28(4), 355-362.

Cooper, M. J., Upton, N., \& Seaman, S. (2005). Customer relationship management: A comparative analysis of family and nonfamily business perspectives. Journal of Small Business Management, 46(3), 242-256.

Chua, J. H., Chrisman, J. J., \& Sharma, P. (1999). Defining the family business by behavior. Entrepreneurship Theory and Practice, 23(4), 19-39.

Chua, J. H., Chrisman, J. J., \& Sharma, P. (2003). Succession and nonsuccession concerns of family firms and agency relationships with nonfamily managers. Family Business Review. 16(2), 89-107.

Davis, J. H., Schoorman, F. D., \& Donaldson, L. (1997). Toward a stewardship theory of management. Academy of Management Review, 22(1), 20-47.

Debicki, B., Matherne, C., Kellermanns, F. W. \& Chrisman, J. (2009). Family business research in the new millennium: An overview of the who, the where, the what and the why. Family Business Review, 22(2), 151-166.

De la Cruz Deniz Deniz, M. \& Katiuska Cabrera Suarez, M. (2005). Corporate social responsibility and family business in Spain. Journal of Business Ethics, 56(1), 2741.

Demski, J. S., \& Feltham, G. A. (1978). Economic incentives in budgetary control systems. The Accounting Review, 53(2), 336-359.

Dukerich, J. M., Golden, B. R., \& Shortell, S. M. (2002). Beauty is in the eye of the beholder: The impact of organizational identification, identity, and image on the cooperative behaviors of physicians. Administrative Science Quarterly, 47(3), 507-533.

Dutton, J. E., Dukerich, J. M., \& Harquail. C. V. (1994). Organizational Images and Member Identification. Administrative Science Quarterly 39(2), 239-263.

Dyer, G., \& Whetten, D. A. (2006). Family firms and social responsibility: Preliminary evidence from the S\&P 500. Entrepreneurship Theory and Practice, 30(6), 785802.

Eaton, C., Yuan, L., \& Wu, Z. (2002, December). Reciprocal altruism and the theory of the family firm. Paper presented at the second annual meeting of the Theories of the Family Enterprise, Philadelphia, PA.

Eddleston, K. A. (2008). Commentary: The prequel to family firm culture and stewardship: The leadership perspective of the founder. Entrepreneurship Theory and Practice, 32(6), 1055-1061.

Eddleston, K., Otondo, R., \& Kellermanns, F. W. (2008). Conflict, participative decision making, and multi-generational ownership: A multi-level analysis. Journal of Small Business Management, 46(3), 456-484.

Eisenhardt, K. M. (1989). Agency theory: An assessment and review. Academy of Management Review, 14(1), 57-74.

Ellemers, N., De Gilder, D., \& Haslam, S. A. (2004). Motivating individuals and groups at work: A social identity perspective on leadership and group performance. Academy of Management Review, 29(3), 459-478.

Epitropaki, O., \& Martin, R. (2005). The moderating role of individual differences in the relation between transformational/transactional leadership perceptions and organizational identification. Leadership Quarterly, 16(4), 569-589. 
Eshel, I., Samuelson, L., \& Shaked, A. (1998). Altruists, egoists, and hooligans in a local interaction model. American Economic Review, 88(1), 157-179.

Foreman, P., \& Whetten, D. A. (2002). Members' identification with multiple-identity organizations. Organization Science, 13(6), 618-635.

Gersick, K. E., Davis, J. A., Hampton, M. M., \& Lansberg, I. (1997). Generation to generation: Life Cycles of the family business. Boston, MA: Harvard Business School Press.

Gomez-Mejia, L. R., Nunez-Nickel, M., \& Gutierrez, M. (2001). The role of family ties in agency contracts. Academy of Management Journal, 44(1), 81-95.

Habbershon, T. G., Williams, M. \& MacMillan, I. (2003). A unified systems perspective of family firm performance. Journal of Business Venturing, 18(4), 451-465.

Heck, R. K. Z. \& Trent, E. (1999). The prevalence of family business from a household sample. Family Business Review, 12(3), 209-224.

Hogg, M. A., (2001). A social identity theory of leadership. Personality and Social Psychology Review, 5(3), 194-200.

James, H. S. (1999). What can the family contribute to business? Examining contractual relationships. Family Business Review, 12(1), 61-71.

Janis, I. L. (1972). Victims of groupthink: A psychological study of foreign-policy decisions and fiascoes. Oxford, England: Houghton Mifflin.

Jensen, M. C., \& Meckling, W. H. (1976). Theory of the firm: Managerial behavior, agency costs and ownership structure. Journal of Financial Economics, 3(4), 305-360.

Kepner, E. (1991). The family and the firm: A coevolutionary perspective. Family Business Review, 4(4), 445-461.

Kark, R., \& Shamir, B. (2002). The dual effect of transformational leadership: Priming relational and collective selves and further effects on followers. In B. J. Avolio \& F.J. Yammarino (Eds.), Transformational and Charismatic Leadership: The Road Ahead (pp. 67-91). Amsterdam: JAl: An Imprint of Elsevier Science.

Kramer, R. M. (2006). Social capital and cooperative behavior in the workplace: A social identity perspective. Advances in Group Processes, 23, 1-30.

Le Breton-Miller, I. \& Miller, D. (2009). Agency vs. stewardship in public family firms: A social embeddedness reconciliation. Entrepreneurship Theory and Practice, 33(6), 1169-1191.

Lee, P. M., \& O'Neill, H. M. (2003). Ownership structures and R\&D investments of U.S. and Japanese firms: Agency and stewardship perspectives. Academy of Management Journal, 46(2), 212-225.

Miller, E. J., \& Rice, A. K. (1967). Systems of organization. London, Tavistock.

Mael, F. A., \& Ashforth, B. E. (1992). Alumni and their alma mater: A partial test of the reformulated model of organizational identification. Journal of Organizational Behavior, 13(2), 103-123.

Miller, D. \& Le Breton-Miller, I. (2006). Family governance and firm performance: Agency, stewardship, and capabilities. Family Business Review, 29(1), 73-87.

Ravasi, D., \& Schultz, M. (2006). Responding to organizational identity threats: Exploring the role of organizational culture. Academy of Management Journal, 49(3), 433-458. 
Riketta, M. (2005). Organizational identification: A meta-analysis. Journal of Vocational Behavior, 66(2), 358-384.

Riketta, M., \& van Dick, R. (2005). Foci of attachment in organizations: A meta-analytic comparison of the strength and correlates of workgroup versus organizational identification and commitment. Journal of Vocational Behavior, 67(3), 490-510.

Ross, S. (1973). The economic theory of agency: The principal's problem. American Economic Review, 63(2), 134-139.

Schulze, W. S., Lubatkin, M. H., \& Dino, R. N. (2001). Agency relationships in family firms: Theory and evidence. Organization Science, 12(2), 99-116.

Schulze, W. S., Lubatkin, M. H., \& Dino, R. N. (2003). Toward a theory of agency and altruism in family firms. Journal of Business Venturing, 18(4), 473-490.

Shanker, M. C., \& Astrachan, J. H. (1996). Myths and realities: Family businesses' contribution to the US economy - A framework for assessing family business statistics. Family Business Review, 9(2), 107-123.

Shepherd, D. \& Haynie, J. M. (2009). Family business, identity conflict, and an expedited entrepreneurial process: A process of resolving identity conflict. Entrepreneurship Theory and Practice, 33(6), 1245-1264.

Simon, H. A. (1993). Altruism and economics. American Economic Review, 83(2), 156161.

Stafford, K., Duncan, K. A., Danes, S. M., \& Winter, M. (1999). A research model of sustainable family business. Family Business Review, 12(3), 197-208.

Stewart, A. (2003). Help one another, use one another: Toward an anthropology of family business. Entrepreneurship Theory and Practice, 27(4), 383-396.

Sundaramurthy, C., \& Kreiner, G. E. (2008). Governing by managing identity boundaries: The case of family businesses. Entrepreneurship Theory and Practice, 32(3), 415-436.

Tagiuri, R., \& Davis, J. A. (1996). Bivalent attributes of the family firm. Family Business Review, 9(2), 199-208.

Umphress, E. E., Bingham, J. B., \& Mitchell, M. C. (2010). Unethical behavior in the name of the company: The moderating effect of organizational identification and positive reciprocity beliefs on unethical pro-organizational behavior. Journal of Applied Psychology, 95(4), 769-780.

Vallejo, M. C. (2008). Is the culture of family firms really different? A value-based model for its survival through generation. Journal of Business Ethics. 81(2), 261-279.

Vallejo, M. C. (2009a). The Effects of Commitment of Non-Family Employees of Family Firms from the Perspective of Stewardship Theory. Journal of Business Ethics. 87(3), 379-390.

Vallejo, M. C. (2009b). Analytical model of leadership in family firms under transformational theoretical approach: An exploratory study. Family Business Review, 22(2), 136-150.

van den Berghe, L., \& Carchon, S. (2003). Agency relations within the family business system: An exploratory approach. Corporate Governance: An International Review, 11(3), 171-180.

van Dick, R., Grojean, M. W., Christ, O., \& Wieseke, J. (2006). Identity and the extra mile: Relationships between organizational identification and organizational citizenship behaviour. British Journal of Management, 17(4), 283-301. 
van Knippenberg, D., van Knippenberg, B., De Cermer, D., \& Hogg, M. A. (2004). Leadership, self, and identity: A review and research agenda. Leadership Quarterly, 15(6), 825-856.

van Knippenberg, D. (2000). Work motivation and performance: A social identity perspective. Applied Psychology An International Review, 49(3), 357-371.

van Knippenberg, D., \& van Schie, E. C. M. (2000). Foci and correlates of organizational identification. Journal of Occupational and Organizational Psychology, 73(2), 137-147.

Whetten, D., \& Mackey, A. (2002). A social actor conception of organizational identity and its implications for the study of organizational reputation. Business and Society, 41(4), 393-415.

Williamson, O. (1975). Markets and hierarchies: Analysis and antitrust implications .New York: The Free Press.

Wu, Z. (2001). Altruism and the family firm: Some theory (Unpublished master's economics thesis). University of Calgary.

Zahra, S. A., Hayton, J. C., Neubaum, D. O., Dibrell, C., \& Craig, J. (2008). Culture of family commitment and strategic flexibility: The moderating effect of stewardship. Entrepreneurship Theory and Practice, 32(6), 1035-1054.

Zellweger, T., \& Kellermanns, F. W. (2008, August). Family firm reputation: An investigation of antecedents and performance outcomes. Paper presented at the annual meeting of the Academy of Management, Anaheim, CA. 